\title{
Analysis of the information on rheumatology in the resources of Internet services of opinion-forming dailies and weeklies
}

\section{Analiza informacji na temat reumatologii w zasobach serwisów internetowych dzienników i tygodników opiniotwórczych}

\author{
Rafał Szpakowski ${ }^{1}$, Patrycja Zając ${ }^{2}$ \\ ${ }^{1}$ Department of Early Arthritis, Institute of Rheumatology, Warsaw, Poland \\ ${ }^{2}$ Faculty of Health Sciences, Medical University of Warsaw, Poland, graduate of the nursing division
}

Key words: rheumatology, content analysis, allergology and immunology, mass media.

Słowa kluczowe: reumatologia, analiza treści, alergologia i immunologia, środki masowego przekazu.

\section{Sum mary}

Objectives: The aim of the study was to analyse the contents of the information resources concerning rheumatology on websites of selected opinion-forming dailies and weeklies.

Material and methods: The material used to analyse contents covered information resources of websites of 6 opinion-forming press titles selected on the basis of The best opinion-forming media of 2012 ranking prepared by the Institute for Media Monitoring. The observation units were selected according to their order in the ranking. In the course of quantitative analysis, the following words were used as units of analysis for rheumatologic contents - rheumatism, rheumatic diseases, rheumatoid arthritis, rheumatology, and institute of rheumatology. The complete contents of information resources determined on the basis of quantitative analysis being a unit of analysis/context served, in the course of qualitative analysis, to identify resources which met a specific criterion according to the subjective evaluation of the contents by the authors of analysis. A research procedure identical to the one applied to rheumatology-related subjects was also applied to allergology-related subjects, the only difference being that quantitative analysis did not involve creating a categorization key and units of analysis used in quantitative analysis were allergy, allergy's, and allergology.

Results: A total of 161 resources were identified for rheumatology-related subjects against 234 allergology-related ones. The identified resources came from the period from 1999 (oldest) to 2013 (newest). Among weeklies, most rheumatology-related resources as well as allergology-related resources were published by Wprost (1.4 resources/year and 2.3 resources/year, respectively). Among dailies, most rheumatology-related resources were published by Puls Biznesu while largest allergology-related resources by Gazeta Wyborcza, 5.3 resources/year and 5.4 resources/year, respec-

\section{Streszczenie}

Cel: Analiza treści zasobów informacyjnych dotyczących reumatologii w internetowych serwisach wybranych dzienników oraz tygodników opiniotwórczych.

Materiał i metody: Materiał poddany analizie treści obejmowat zasoby informacyjne internetowych serwisów 6 czasopism opiniotwórczych, wytypowanych na podstawie rankingu Najbardziej opiniotwórczych mediów w 2012 r., opracowanego przez Instytut Monitorowania Mediów. Jednostki obserwacji zostały wybrane wg kolejności w rankingu. W toku analizy ilościowej dla tematyki reumatologicznej użyto następujących słów jako jednostek analizy: reumatyzm, choroby reumatyczne, reumatoidalne zapalenie stawów, reumatologia, instytut reumatologii. Następnie w toku analizy jakościowej, dla której jednostką analizy/kontekstu była pełna treść określonego zasobu informacyjnego wytypowanego na podstawie jednostki analizy ilościowej, wyłoniono zasoby, które wg subiektywnej oceny treści przez autorów spełniały określone kryterium. Identyczne postępowanie badawcze jak dla tematyki reumatologicznej zastosowano dla tematyki alergologicznej, z tą różnicą, że analiza jakościowa nie obejmowała utworzenia klucza kategoryzacyjnego, a jako jednostki analizy ilościowej przyjęto słowa: alergia, alergii, alergologia.

Wyniki: Zidentyfikowano 161 zasobów dla tematyki reumatologicznej, natomiast dla tematyki alergologicznej zidentyfikowano 243 zasoby. Wyszukane zasoby pochodzity z okresu od 1999 r. (najstarszy) do 2013 r. (najnowszy) - wśród tygodników najwięcej zasobów o tematyce reumatologicznej opublikował Wprost (1,4 zasobu/rok), o tematyce alergologicznej również Wprost (2,3 zasobu/rok). Wśród dzienników najwięcej o tematyce reumatologicznej opublikował Puls Biznesu (5,3 zasobu/rok), o tematyce alergologicznej najwięcej Gazeta Wyborcza (5,4 zasobu/rok). Analiza jakościowa zasobów związanych z reumatologią wykazała, iż najczęściej zasoby te miały

Address for correspondence:

Rafał Szpakowski, MA, Institute of Rheumatology, Spartańska 1, 02-637 Warsaw, Poland, e-mail: rafszpakowski@gmail.com

Submitted: 24.05.2014 
tively. The qualitative analysis of rheumatology-related resources revealed these resources primarily had a character of scientific reports ( $n=29 ; 18 \%)$ and educational campaigns ( $n=44 ; 27 \%)$. Conclusions: Viewed against allergology and basing on websites of dailies and weeklies studied, rheumatology seems to be a subject given less attention in opinion-forming media. Rheumatology-related resources are characterised primarily by positive message.

This publication is dedicated to all of nurses, doctors and public health specialists connected with rheumatology who, through their commitment and dedication, create a positive image of rheumatology in the society.

\section{Introduction}

Mass media play an important role in forming public opinion ("social awareness"). People who do not have direct contact with for example rheumatologists or rheumatology out-patient clinics often form their opinions and make decisions based on e.g. what they read in the press. For this reason, it is important to constantly monitor communications environment. Constant observation allows for adequate response to the alarming signals from the environment [1]. One of the methods of observation of the communications environment is content analysis. Content analysis is based on the creative elaboration of the quality of existing data and creation of useful reports [2]. The content analysis was used in qualitative and quantitative versions to assess the image of rheumatology in the opinion-forming media. In addition, quantitative analysis of the content was used in a comparative analysis relative to allergology. The reason for the selection of allergology was similar nature of both medical disciplines associated with immune disorders. The comparative analysis was used to determine the validity of one discipline relative to the other in opinion-forming media.

\section{Aim of the study}

The main aim of the research carried out was a quantitative and qualitative analysis of the content of information resources concerning rheumatology on the websites of selected opinion-forming dailies and weeklies, including a determination of the subject range of the rheumatology-related information, a determination of an indicator of the annual number of rheumatology-related resources for dailies and weeklies as well as an identification of the frequency of publication of rheumatology-related resources over the past years and a determination of the interest of opinion-forming media in rheumatology as compared with allergology. charakter doniesień naukowych ( $n=29 ; 18 \%)$ oraz kampanii edukacyjnych ( $n=44 ; 27 \%)$.

Wnioski: Na podstawie zasobów serwisów internetowych analizowanych dzienników i tygodników reumatologia w porównaniu z alergologią jest tematem, któremu media opiniotwórcze poświęcają mniej uwagi. Zasoby reumatologiczne charakteryzują się głównie pozytywnym przekazem.

\section{Material and methods}

The material used in the analysis of the content covered information resources of the websites of 6 opinion-forming press titles selected on the basis of the ranking of The best opinion-shaping media of 2012 prepared by the Institute for Media Monitoring [3]. The term "information resources" refers to all and any information available within a given website of a given press title, however with the exclusion of forums and blogs as well as resources available only after redirection to another website (e.g. gover.pl; infotuba.pl), except for redirections, which are contained within a given website thus are sub-websites or, in other words, subject websites (e.g. in the case of the Puls Biznesu website, the analysis covered also the contents to be found within pulsmedycyny.pl or pulsfarmacji.pl).

The observation units were selected according to their order in the ranking of The best opinion-forming media of 2012 [3] commencing from top ranking opinion-forming press titles. And thus, the analysis included the first three weeklies (i.e. Wprost [4], Newsweek [5], Polityka [6]) and three dailies (i.e. Gazeta Wyborcza [7], Rzeczpospolita [8], Puls Biznesu [9]) from the first 4 dailies of the ranking, excluding the daily that had the $3^{\text {rd }}$ place in the ranking (i.e. Dziennik Gazeta Prawna [10]) because of lack of free-of-charge access to information resources prior to September 2009.

The analysed contents concerned materials available on 17 September 2013 (with no time limit publications) as well as materials the access to which was full and free of charge on the day referred to. In the course of the quantitative analysis, the following words were used as units of analysis for the rheumatology-related contents - rheumatism, rheumatic diseases, rheumatoid arthritis, rheumatology, and institute of rheumatology. The complete contents of the information resources determined on the basis the quantitative analysis being a unit of analysis/ context served, in the course of the qualitative analysis, to identify resources, which met a specific criterion according to the subjective evaluation of the contents by the author of the analysis. The criterion was deemed to be fulfilled when the rheumatology-related thread was the only or the leading thread present in the content of the resource (with the leading implying that broadly un- 
derstood rheumatology-related subjects were the main reason for the publication while the other threads could be considered as 'accompanying', that is not constituting the main theme of the resource) and also when the rheumatology-related thread was in substance balanced against other threads. The qualitative analysis used open/explorative coding - after the qualitative analysis of the object of the contents of information resources (i.e. an analysis of what a given resource concerned) was carried out, a categorization key was constructed.

Aresearch procedure identical to the one adopted to rheumatology-related subjects was applied to allergology- related subjects, the difference being that the qualitative analysis did not involve creation of a categorization key and the words used as units of quantitative analysis were: allergy, allergy's, and allergology. Qualitative analysis was not applied to allergology-related subjects because of the main goal of the study was the rheumatology-related issue. The allergology-related issue was only used as a benchmark in quantitative analysis for rheumatology.

The resources concerning rheumatology-related subjects were classified thematically according to the categorization key developed by the author of the study in the course of the qualitative evaluation (Table I).

Table I. Categorization key developed in the course of qualitative analysis

\begin{tabular}{|c|c|}
\hline \multicolumn{2}{|r|}{ Categorization key } \\
\hline Title of category & Description of category \\
\hline 'biological therapy’ & $\begin{array}{l}\text { A category concerning resources describing strictly biological treatment, questions related to } \\
\text { biological treatment connected with refunding or information of a scientific report character } \\
\text { being excluded }\end{array}$ \\
\hline 'refund of drugs/therapy' & $\begin{array}{l}\text { A category describing changes in the refunding of drugs by the National Health Fund, includ- } \\
\text { ing the refund of biological treatment }\end{array}$ \\
\hline 'staff changes' & $\begin{array}{l}\text { A category describing personnel changes in positions at treatment units as well as in the } \\
\text { position of the national consultant for rheumatology }\end{array}$ \\
\hline 'organization of treatment' & $\begin{array}{l}\text { A category describing these changes in the organization of treatment which are not of an } \\
\text { innovative/pioneering character but concern primarily changes in the functioning of such de- } \\
\text { cision-making organs of health-related public institutions as, for instance, the Coordination } \\
\text { Team for Biological Treatment in Rheumatic Diseases, excluding innovation issues such as, } \\
\text { for instance, the establishment of, for instance, the Rheumatologic Register of Patients (RRP) }\end{array}$ \\
\hline 'quality of treatment' & $\begin{array}{l}\text { A category describing resources concerning both newly-opened units, new organizational } \\
\text { units within already existing therapeutic units and organizational changes which may be } \\
\text { deemed pioneering or innovative such as, for example, the establishment of the RRP or other } \\
\text { organization systems which can be considered contributory to improving quality from the } \\
\text { point of view of both in- and out-patients }\end{array}$ \\
\hline $\begin{array}{l}\text { 'available methods of therapy/ } \\
\text { diagnosis' }\end{array}$ & $\begin{array}{l}\text { A category referring to resources which concern the available methods of treatment as well } \\
\text { as possible diagnostic methods of use in diagnosing rheumatic diseases, excluding the infor- } \\
\text { mation on therapy/diagnostic methods which is connected with innovativeness, that is of } \\
\text { a scientific report character }\end{array}$ \\
\hline 'scientific reports' & $\begin{array}{l}\text { A category covering all and any resources concerning scientific research, research findings, } \\
\text { research in progress as well as new guidelines referring to schemes of treatment }\end{array}$ \\
\hline $\begin{array}{l}\text { 'financial costs of disease } \\
\text { treatment' }\end{array}$ & $\begin{array}{l}\text { A category embracing resources concerned with costs of treating rheumatic diseases on the } \\
\text { micro and macroeconomic scale }\end{array}$ \\
\hline $\begin{array}{l}\text { 'financial problems in rheuma- } \\
\text { tology' }\end{array}$ & $\begin{array}{l}\text { A category covering resources concerning the indebtedness of therapeutic units and resultant } \\
\text { patient admission limitations }\end{array}$ \\
\hline 'legislative barriers' & $\begin{array}{l}\text { A category describing resources concerning legal barriers making the provision of patient's } \\
\text { point of view adequate and justified health care services difficult }\end{array}$ \\
\hline $\begin{array}{l}\text { 'withdrawal of a drug from } \\
\text { the market' }\end{array}$ & $\begin{array}{l}\text { A category referring to resources informing about drugs which used to be applied in treatment } \\
\text { for some time but which further research then showed to have side effects outweighing pos- } \\
\text { sible therapeutic effects }\end{array}$ \\
\hline ‘educational campaign’ & $\begin{array}{l}\text { A category describing resources which concern experts' answers to questions posed by read- } \\
\text { ers as well as epidemiological information, raising social-awareness about rheumatic diseas- } \\
\text { es, including life with the disease as well as all and any educational (social) campaigns }\end{array}$ \\
\hline 'treatment accessibility' & $\begin{array}{l}\text { A category describing resources concerning queues to rheumatologists as well as difficulties } \\
\text { in access to treatment }\end{array}$ \\
\hline
\end{tabular}


The above presented subjective division into subject categories was assigned to the resources studied according to their only/'leading' thread. The assignment of one resource to a number of subject categories may seem closer to the actual subject picture of the resources. However, the simplification consisting of the selection of one subject for a given resource was primarily intended to expose major subject threads taken up by the media in the domain of rheumatology. Simultaneously, any side threads of the resources which were not a part of the leading thread of the resource were ignored.

\section{Results}

A total of 161 resources on rheumatology-related subjects were identified, including a total of 131 resources in dailies: in Gazeta Wyborcza - 26 items, in Rzeczpospolita - 26, in Puls Biznesu - 79; and a total of 30 resources in weeklies: Wprost - 21 items, Newsweek - 6, and Polityka - 3. By comparison, a total of 243 resources concerning allergology was found, including in dailies: a total of 194 resources: Gazeta Wyborcza 80 items, Rzeczpospolita - 39, Puls Biznesu - 75; while in weeklies: a total of 49 resources: Wprost - 34 items, Newsweek - 14, and Polityka-1.

The identified resources come from the period from 1999 (oldest) to 2013 (newest). Wprost (1.4 resources/ year) had the largest number of rheumatology-related resources among weeklies. It is worth mentioning that Wprost published 8 resources in 2012, which has a significant impact on the indicator. It was followed by Newsweek (0.4 resource/year) and Polityka (0.2 resource/year) (Fig. 1). In allergology-related subjects
Wprost came first among weeklies with 2.3 resources/ year and was followed by Newsweek with 0.9 resource/ year and Polityka with 0.07 resource/year (Fig. 1). Among dailies, Puls Biznesu published the largest number of rheumatology-related resources (5.3 resources/ year) and was followed ex aequo by Rzeczpospolita and Gazeta Wyborcza (1.7 resources/year) (Fig. 2). The largest number of allergology-related resources in dailies appeared in Gazeta Wyborcza (5.4 resources/year). It is worth mentioning that Gazeta Wyborcza published 32 resources in 2012 and 27 resources in 2013, which had a significant impact on the indicator. Puls Biznesu and Rzeczpospolita followed with 5.0 and 2.6 resources/year, respectively (Fig. 2). Among weeklies, the largest number of rheumatology-related resources was published in 2012 while no resources appeared in 2003 (Fig. 3). The largest number of allergology-related resources appeared in weeklies in 2013 while the lowest in 2001 and 2003 (Fig. 3). Among dailies, the largest number of rheumatology-related resources was published in 2012 while no resources appeared in 2002, 2001, and 1999 (Fig. 4). The largest number of allergology-related resources appeared in dailies in 2012 while no resources were published in 2002, 2001, and 1999 (Fig. 4). Most frequently, the content of rheumatology-related resources found in weeklies concerned the 'educational campaign' category ( $n=10 ; 33 \%)$ and 'scientific reports' category ( $n=7 ; 23 \%$ ) (Fig. 5). In dailies, the content of rheumatology-related resources concerned, most frequently, the 'educational campaign' category $(n=34$; $26 \%)$ and the 'scientific reports' category $(n=22 ; 17 \%)$, followed by 'available methods of treatment/diagnosis' $(n=18 ; 14 \%)$ and 'quality of treatment' $(n=14 ; 11 \%)$ categories (Fig. 5).

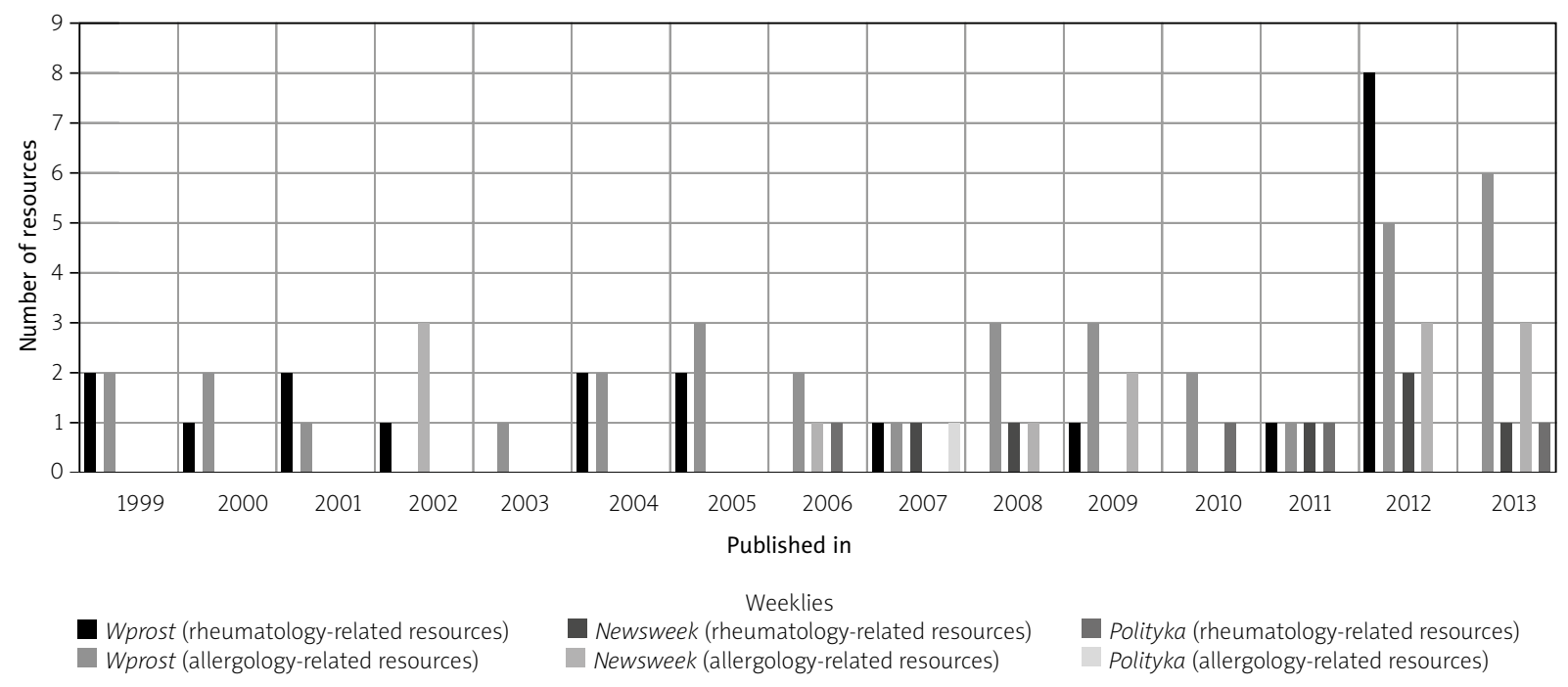

Fig. 1. Number of rheumatology- and allergology-related resources (weeklies) by year. 


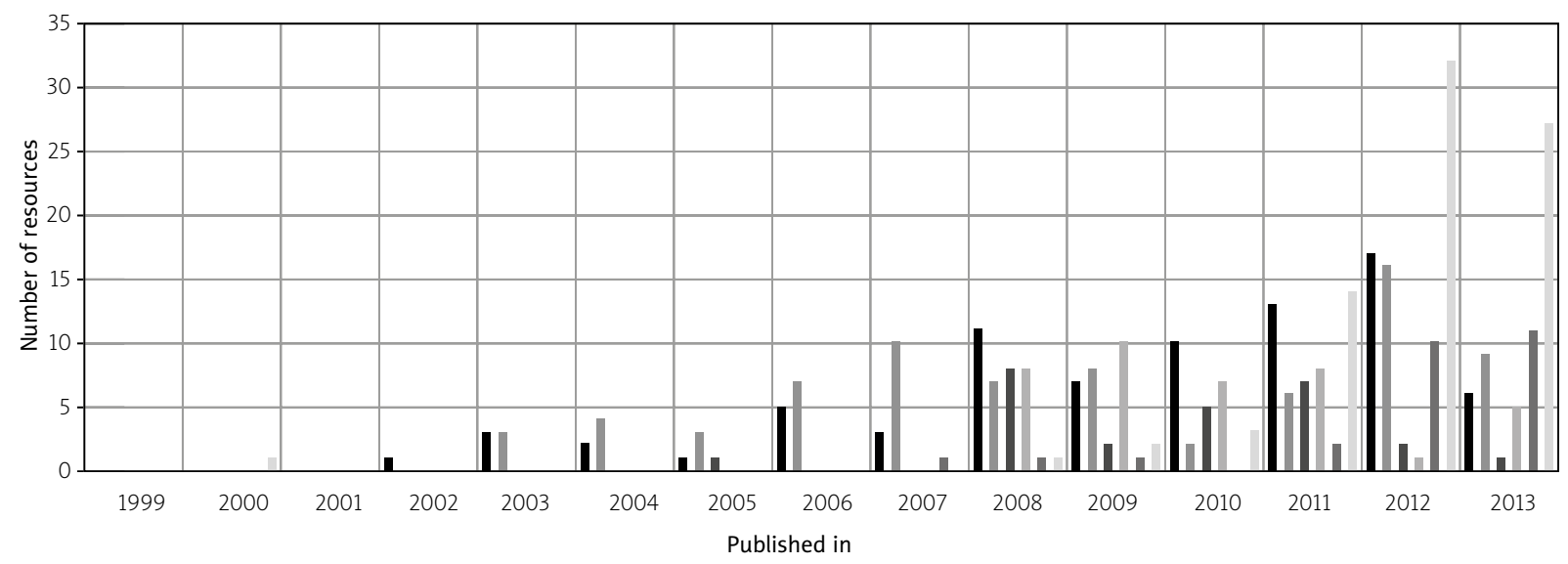

Dailies

Puls Biznesu (rheumatology-related resources) Rzeczpospolita (rheumatology-related resources) Puls Biznesu (allergology-related resources)

Fig. 2. Number of rheumatology- and allergology-related resources (dailies) by year.

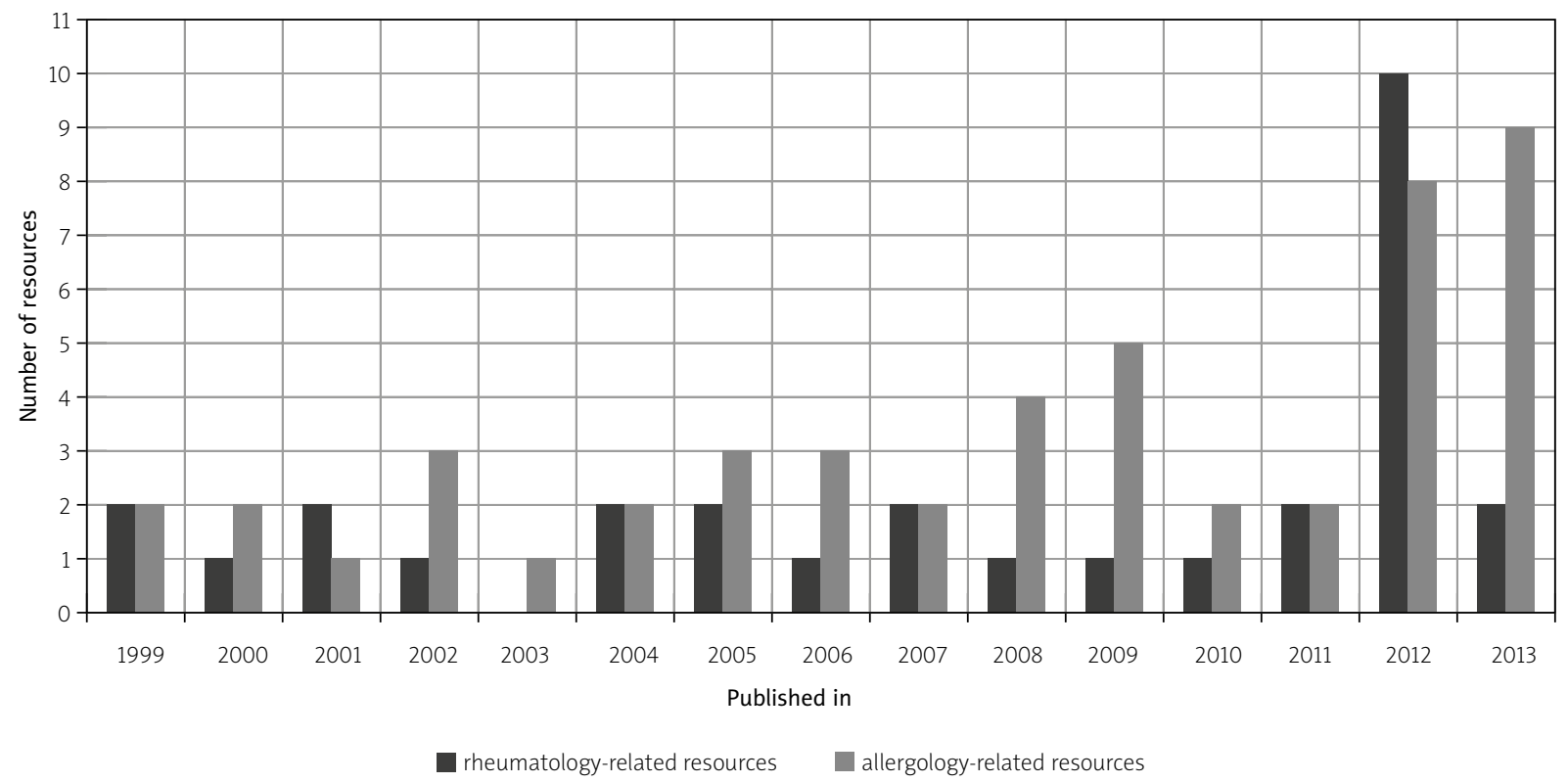

Fig. 3. Number of rheumatology- and allergology-related resources in 1999-2013. Aggregated results for the weeklies.

\section{Discussion}

The growing interest in both rheumatology- and allergology-related subjects on the studied websites of opinion-forming weeklies and dailies over the past years (3-5 years) may yet fail to present the actual picture of the situation due to incomplete electronic resources for the earlier period which stemmed from the absence of adequate efforts on the part of publishers to place press information/editions on websites. The present development of technology (e.g. tablets, mobile Internet) as well as a larger number of Internet users have contributed to a more increased interest in the expansion of Internet resources by broadly understood media.

In spite of a small number of rheumatology-related resources (as compared with allergology-related resources), it may be a source of satisfaction (for healthcare workers related to rheumatology) that the media studied created information of a primarily awareness-raising and rheumatology-promoting character, that is positive rather than pejorative as it did not focus on irregularities in drug/treatment refunding, medical/diagnostic 


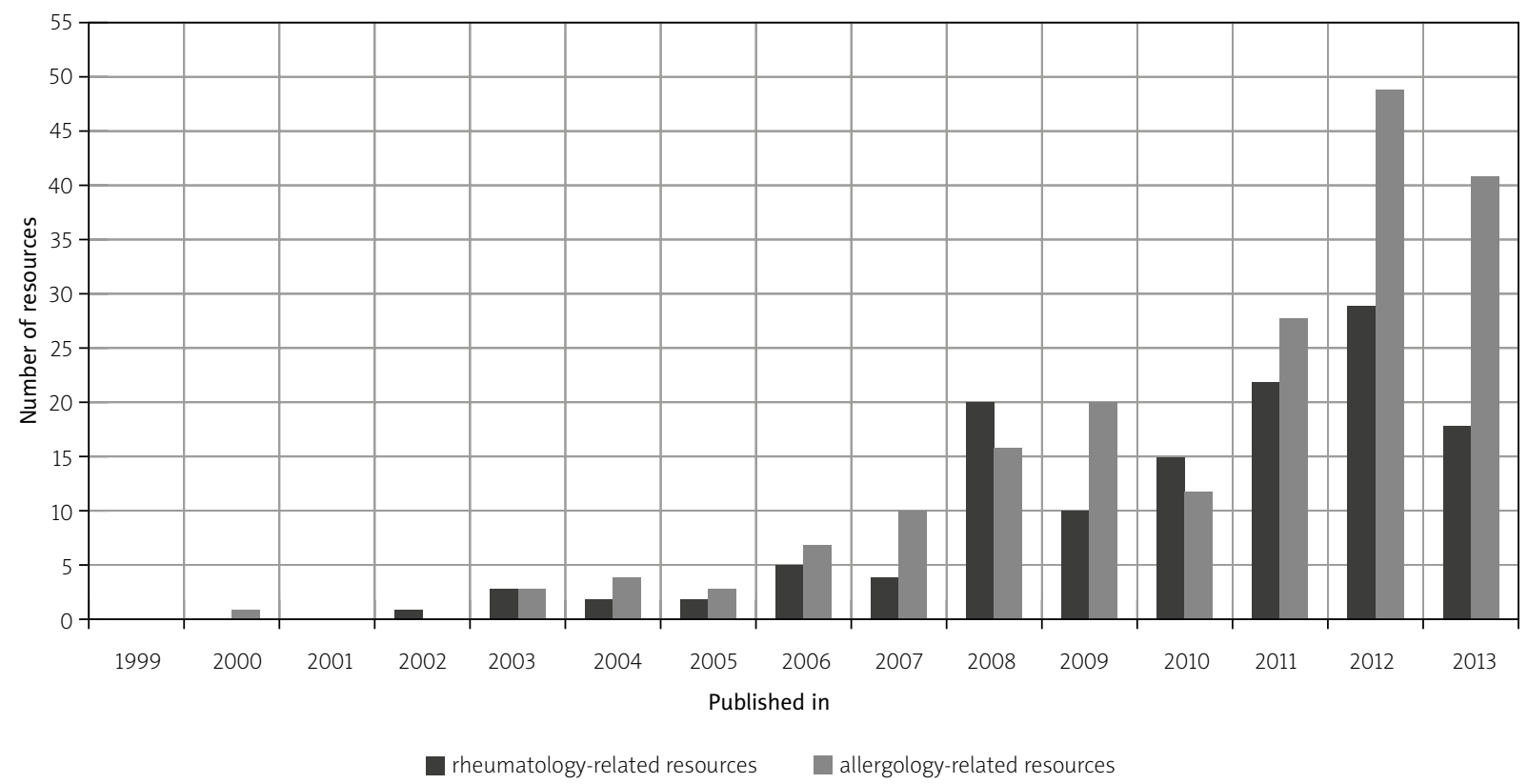

Fig. 4. Number of rheumatology- and allergology-related resources in 1999-2013. Aggregated results for the dailies.

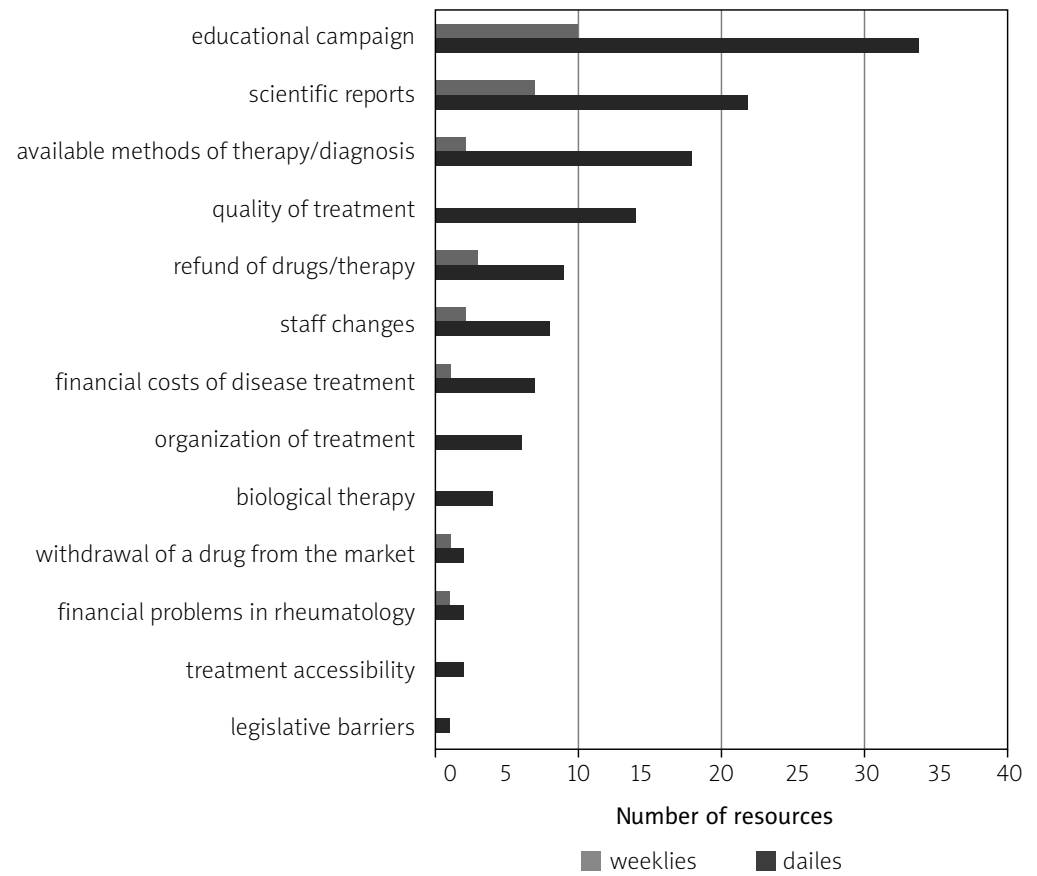

Fig. 5. The rheumatology-related subjects (dailies and weeklies).

mistakes or a negative picture of people with rheumatic diseases.

There is no other publication on content analysis in the area of communication activities in the field of rheumatology. Accordingly, the publication contains no reference to other authors.

\section{Conclusions}

Viewed against the number of allergology-related resources, the number of rheumatology-related resources shows that broadly understood allergology is a subject tackled in press publications, on the websites of both 
weeklies and dailies studied, more frequently than rheumatology, in spite of immunological disturbances being their common denominator.

The past 3-5 years have witnessed a growing interest in both rheumatology and allergology on the websites of the dailies and weeklies studied.

The qualitative analysis of the contents of rheumatology-related resources of the websites of selected weeklies and dailies seems to indicate their contribution to creating a positive/optimistic picture of rheumatology among the audience of the press studied.

The authors would like to express their deepest gratitude to Filip Raciborski, PhD for valuable time and substantive advice that helped to create the present publication. The authors also extend compliments Aneta Tomaszewska, PhD for editorial comments.

The authors declare no conflict of interest.

\section{References}

1. Poznańska A. Komunikacja medialna a sfera publiczna. Szanse i zagrożenia. Karkonoska Państwowa Szkoła Wyższa. Jelenia Góra 2012

2. Makowska M. Analiza danych zastanych. Wyd. SCHOLAR. Warszawa 2013.

3. Instytut Monitorowania Mediów. Najbardziej opiniotwórcze polskie media w 2012 roku. Warszawa. 2013. http://www.instytut.com.pl/ [11.09.2013].

4. http://www.wprost.pl/ [17.09.2013].

5. http://www.newsweek.pl/ [17.09.2013].

6. http://www.polityka.pl/ [17.09.2013].

7. http://wyborcza.pl/ [17.09.2013].

8. http://www.rp.pl/ [17.09.2013].

9. http://www.pb.pl/ [17.09.2013].

10. http://www.gazetaprawna.pl/ [17.09.2013]. 